\title{
High glucose and oxidative/nitrosative stress conditions induce apoptosis in retinal endothelial cells by a caspase-independent pathway
}

\author{
Ermelindo C. Leal $^{\mathrm{a}, \mathrm{b}}$, Célia A. Aveleira ${ }^{\mathrm{a}}$, Áurea F. Castilho ${ }^{\mathrm{a}}$, Andreia M. Serra ${ }^{\mathrm{a}}$, Filipa I. Baptista ${ }^{\mathrm{a}}$, \\ Ken-Ichi Hosoya ${ }^{c}$, John V. Forrester ${ }^{\mathrm{d}}$, António F. Ambrósio ${ }^{\mathrm{a}, \mathrm{b}, *}$ \\ ${ }^{\text {a } C e n t e r ~ o f ~ O p h t h a l m o l o g y, ~ I B I L I, ~ F a c u l t y ~ o f ~ M e d i c i n e, ~ U n i v e r s i t y ~ o f ~ C o i m b r a, ~ P o r t u g a l ~}$ \\ ${ }^{\mathrm{b}}$ Center for Neuroscience and Cell Biology, University of Coimbra, Coimbra, Portugal \\ ' Graduate School of Medical and Pharmaceutical Sciences, University of Toyama, Toyama, Japan \\ ${ }^{\mathrm{d}}$ Institute of Medical Sciences, Department of Ophthalmology, University of Aberdeen, Aberdeen, UK
}

\section{A R T I C L E I N F O}

\section{Article history:}

Received 5 August 2008

Accepted in revised form 19 December 2008

Available online $\mathrm{xxx}$

\section{Keywords:}

diabetic retinopathy

apoptosis

AIF

caspase

endothelial cell

oxidative/nitrosative stress

\begin{abstract}
A B S T R A C T
Diabetic retinopathy (DR) is a leading cause of vision loss among working-age adults. Retinal endothelial cell apoptosis is an early event in DR, and oxidative stress is known to play an important role in this pathology. Recently, we found that high glucose induces apoptosis in retinal neural cells by a caspaseindependent mechanism. Here, we investigated the mechanisms underlying retinal endothelial cell apoptosis induced by high glucose and oxidative/nitrosative stress conditions. Endothelial cells (TRiBRB2 rat retinal endothelial cell line) were exposed to high glucose (long-term exposure, 7 days), or to NOC-18 (nitric oxide donor; $250 \mu \mathrm{M}$ ) or $\mathrm{H}_{2} \mathrm{O}_{2}(100 \mu \mathrm{M})$ for $24 \mathrm{~h}$. Cell viability was assessed by the MTT assay and cell proliferation by [methyl $\left.{ }^{3} \mathrm{H}\right]$-thymidine incorporation into DNA. Apoptotic cells were detected with Hoechst or Annexin V staining. Active caspases were detected by an apoptosis detection kit. Active caspase-3 and apoptosis-inducing factor (AIF) protein levels were assessed by Western blot or immunohistochemistry. High glucose, NOC-18 and $\mathrm{H}_{2} \mathrm{O}_{2}$ increased apoptosis in retinal endothelial cells. High glucose and mannitol decreased cell proliferation, but mannitol did not induce apoptosis. Caspase activation did not increase in high glucose- or NOC-18-treated cells, but it increased in cells exposed to $\mathrm{H}_{2} \mathrm{O}_{2}$. However, the protein levels of AIF decreased in mitochondrial fractions and increased in nuclear fractions, in all conditions. These results are the first demonstrating that retinal endothelial cell apoptosis induced by high glucose is independent of caspase activation, and is correlated with AIF translocation to the nucleus. NOC-18 and $\mathrm{H}_{2} \mathrm{O}_{2}$ also activate a caspase-independent apoptotic pathway, although $\mathrm{H}_{2} \mathrm{O}_{2}$ can also induce caspase-mediated apoptosis.
\end{abstract}

(c) 2008 Elsevier Ltd. All rights reserved.

\section{Introduction}

Diabetic retinopathy (DR) is a leading cause of vision loss and blindness in working-age adults in developed countries, and hyperglycemia is known to be the prime-triggering factor for the progression of the disease (The Diabetes Control and Complications Trial Research Group, 1993; UK Prospective Diabetes Study (UKPDS) Group, 1998). DR is considered to be a microvascular disease and some of the early events include loss of endothelial cells and pericytes, capillary occlusion and blood-retinal barrier (BRB) breakdown (Cunha-Vaz, 1983; Hammes, 2005; Lorenzi and Gerhardinger, 2001).

\footnotetext{
* Corresponding author. Center of Ophthalmology, IBILI, Faculty of Medicine, University of Coimbra, Azinhaga de Santa Comba - Celas, 3004-548 Coimbra, Portugal. Tel.: +351 239480 222; fax: +351 239480280

E-mail address: fambrosio@ibili.uc.pt (A.F. Ambrósio).
}

Apoptosis, or programmed cell death, appears to play an important role in the development and pathogenesis of diabetic complications (Allen et al., 2005). Generally, apoptosis is believed to be the result of caspase activation. Caspases are present in living cells as inactive zymogens that become activated when cells are exposed to stress conditions. There are two well-characterized caspase cascades: one is initiated by the activation of death receptors located at cell surface, such as Fas and tumor necrosis factor, leading to caspase- 8 activation, which in turn cleaves and activates downstream caspases such as caspase-3, -6, and -7 (Srinivasula et al., 1996); the other cascade is triggered by cytochrome $c$ released from mitochondria, which promotes the activation of caspase-9 through APAF-1 and subsequently other caspases, including caspase-3, resulting in the execution of apoptosis ( $\mathrm{Li}$ et al., 1997; Zou et al., 1999). Several well-characterized morphological features of apoptosis include chromatin condensation and fragmentation, and formation of apoptotic bodies. 
Diabetic human and rat retinas develop acellular capillaries, and this event is associated with endothelial cell apoptosis (Dagher et al., 2004). Also, several in vitro studies have demonstrated that high glucose increases apoptosis in retinal endothelial cells (Du et al., 2003; Kowluru and Abbas, 2003; Kowluru and Koppolu, 2002). Retinal endothelial cell apoptosis, induced by hyperglycemia, was shown to be due to mitochondrial dysfunction associated with cytochrome c release and caspase activation (Kowluru and Abbas, 2003; Kowluru and Koppolu, 2002). Also, oxidative/ nitrosative stress is increased in the retina in diabetes, and the use of antioxidants inhibits high glucose-induced mitochondrial dysfunction, activation of caspase-3, and cell death in retinal capillary cells (Kowluru, 2005; Kowluru and Koppolu, 2002).

Apoptosis-inducing factor (AIF) is considered to be involved in an apoptotic pathway that is independent of caspase activation (Susin et al., 1999). AIF is a flavoprotein of approximately 62-kDa, in the mature form, that is normally located in the inner mitochondrial membrane. Upon induction of apoptosis, AIF is processed to an approximately $57-\mathrm{kDa}$ form in the mitochondrial intermembrane space, being released into the cytoplasm and then translocated into the nucleus where mediates apoptosis (Otera et al., 2005). Microinjection of AIF into the cytoplasm of intact cells induces typical apoptotic features, such as condensation of chromatin and exposure of phosphatidylserine (PS) at the outer leaflet of the plasma membrane (Joza et al., 2001). Recently, we provided evidence, for the first time, that high glucose-induced apoptosis in retinal neural cells is correlated with AIF translocation from the mitochondria to the nucleus (Santiago et al., 2007). In addition, weak immunoreactivity for AIF was shown to be present in human diabetic retinas in different cell types (Abu El-Asrar et al., 2007). Apoptosis mediated by AIF has been detected in endothelial cells in response to pro-inflammatory stimuli or after ischemia-reperfusion (Zhang et al., 2003, 2005). However, to date, there are no studies showing that high glucose can activate an apoptotic pathway independent of caspases in endothelial cells.

Since endothelial cell apoptosis is a main feature of DR, and oxidative/nitrosative stress plays a major role in this pathology, the main purpose of this study was to investigate the molecular mechanisms underlying high glucose- and oxidative/nitrosative stress-induced retinal endothelial cell apoptosis. To date, retinal endothelial cell death caused by hyperglycemic conditions has been associated to caspase-mediated apoptotic processes. However, since it has been shown in many diseases that apoptosis can be also mediated by a caspase-independent pathway, we investigated the potential involvement of both pathways in retinal endothelial cell apoptosis induced by hyperglycemic or oxidative/ nitrosative stress conditions. The identification of novel molecular mechanisms underlying endothelial cell death in the retina will give insight into the pathogenesis of DR and may be useful to develop new therapeutic strategies.

\section{Material and methods}

\subsection{Materials}

Fetal bovine serum (FBS) and Dulbecco's Modified Eagle's Medium (DMEM, low glucose) were purchased from Invitrogen Corporation (GIBCO; Paisley, UK). NOC-18, a nitric oxide donor, was purchased from Alexis Biochemicals (San Diego, CA, USA). Carboxyfluorescein FLICA Apoptosis detection kit was purchased from Immunochemistry Technologies, LLC (Bloomington, MN, USA). The antibody anti-caspase- 3 was purchased from Cell Signalling Technology (Danvers, MA, USA) and the anti-AIF antibody was purchased from Santa Cruz Biotechnology (Santa Cruz, CA, USA). The Universol scintillation cocktail was obtained from ICN (Irvine,
CA, USA). The bicinchoninic acid (BCA) protein assay kit was purchased from Pierce Biotechnology (Rockford, USA). The [methyl- ${ }^{3} \mathrm{H}$ ]-thymidine, the polyvinylidene difluoride (PVDF) membranes, the alkaline phosphatase-linked anti-rabbit and antimouse secondary antibodies and the enhanced chemifluorescence (ECF) reagent were obtained from Amersham Biosciences (Uppsala, Sweden). Other reagents used in immunoblotting experiments were purchased from Bio-Rad (Hercules, CA, USA). The complete mini protease inhibitor cocktail tablets were purchased from Roche (Basel, Switzerland). All other reagents were from Sigma Chemical Corporation (St. Louis, USA) and Merck (Darmstadt, Germany).

\subsection{Retinal endothelial cell culture}

The endothelial cell line (TR-iBRB2) was established by Hosoya et al. (2001) from a transgenic rat harboring the temperaturesensitive simian virus 40 (SV 40) large T-antigen gene. Rat retinal endothelial cells were cultured in low glucose $(5.5 \mathrm{mM})$ DMEM containing $10 \%$ heat-inactivated FBS, $17.8 \mathrm{mM}$ sodium bicarbonate, $0.1 \mathrm{mg} / \mathrm{ml}$ streptomycin and $100 \mathrm{IU} / \mathrm{ml}$ penicillin. Cells were maintained at $33^{\circ} \mathrm{C}$ in a humidified atmosphere of $5 \% \mathrm{CO}_{2} / 95 \%$ air. Cells were incubated with $24.5 \mathrm{mM}$ glucose (final concentration $30 \mathrm{mM}$ ) or with $24.5 \mathrm{mM}$ mannitol (widely used osmotic control), for 7 days (long-term exposure to mimic chronic hyperglycemia). Endothelial cells were also incubated with $250 \mu \mathrm{M}$ NOC-18 or $100 \mu \mathrm{M} \mathrm{H}_{2} \mathrm{O}_{2}$, for $24 \mathrm{~h}$, as indicated in the figure legends.

\subsection{MTT assay}

Cell viability was assessed using the 3-(4,5-dimethylthiazol-2yl)-2,5-diphenyltetrazolium bromide (MTT) colorimetric assay. MTT, when taken up by living cells, is converted from a yellow to a water insoluble blue-colored precipitate by cellular dehydrogenases (Mosmann, 1983). Briefly, Krebs buffer (132 mM NaCl, $4 \mathrm{mM}$ $\mathrm{KCl}, 1.4 \mathrm{mM} \mathrm{MgCl}, 1 \mathrm{mM} \mathrm{CaCl} 2,6 \mathrm{mM}$ glucose, $10 \mathrm{mM}$ Hepes-Na, $\mathrm{pH}$ 7.4) with MTT $(0.5 \mathrm{mg} / \mathrm{ml})$ was added to the cultures and incubated for $2 \mathrm{~h}$ at $37{ }^{\circ} \mathrm{C}$ in the incubation chamber. The precipitated dye formed was dissolved in $0.04 \mathrm{M} \mathrm{HCl}$ in isopropanol and quantitated colorimetrically (absorbance at $570 \mathrm{~nm}$ ). All experiments were carried out in triplicate.

\subsection{Proliferation assay}

Cell proliferation was measured by a [methyl- ${ }^{3} \mathrm{H}$-thymidine incorporation assay. In brief, retinal endothelial cells were plated in 12 -well tissue culture plates and allowed to grow to $60 \%$ confluence. For cell synchronization, $24 \mathrm{~h}$ before thymidine incubation media was changed to serum free media. Cells were incubated with [methyl- ${ }^{3} \mathrm{H}$ ]-thymidine $(1 \mu \mathrm{Ci}$ per well) for $10 \mathrm{~h}$. After washing cells with ice-cold PBS, they were lysed with ice-cold $10 \%$ trichloroacetic acid (TCA) in PBS and left for $20 \mathrm{~min}$ at $4{ }^{\circ} \mathrm{C}$. Then, ice-cold $0.2 \mathrm{M}$ sodium hydroxide $(\mathrm{NaOH})$ was added to cell lysates for $10 \mathrm{~min}$ at $-20^{\circ} \mathrm{C}$. Cell lysates were collected and the Universol scintillation cocktail $(2.5 \mathrm{ml})$ was added. The incorporation of [methyl- ${ }^{3} \mathrm{H}$ ]thymidine into DNA was assessed determining the $\mathrm{dpm}$ in a liquid scintillation counter (Packard 2000; Packard, Canberra, Australia).

\subsection{Detection of apoptotic cells}

Cells undergoing apoptosis were identified by (a) Hoechst 33342 staining and by (b) Annexin V/propidium iodide (PI) double staining.

(a) Hoechst 33342 dye labels the nuclei of all cells. Cells with condensed or fragmented chromatin were considered 
apoptotic. Briefly, cells were fixed in methanol:acetone (1:1) for $10 \mathrm{~min}$ and stained with Hoechst $(5 \mathrm{mg} / \mathrm{ml}$ ) for $5 \mathrm{~min}$. Cells were visualized under an inverted fluorescence microscope (Zeiss, Gottingen, Germany) (excitation at $365 \mathrm{~nm}$ and emission at $480 \mathrm{~nm}$, using an UV-filter). A minimum of 300 cells in each coverslip, from 6 to 7 randomly selected fields, were counted, and apoptotic cells were expressed as percentage of total cell counts.

(b) Apoptosis was also characterized by the analysis of phosphatidylserine translocation to the outer leaflet of plasma membrane by flow cytometry, using Annexin V conjugated with fluorescein isothiocyanate (FITC) and propidium iodide (PI). After gentle trypsinization, that was stopped by adding DMEM containing 10\% FBS, endothelial cells were dissociated and collected. Then, cells were washed in PBS (137 mM NaCl, $2.7 \mathrm{mM} \mathrm{KCl}, 10 \mathrm{mM} \mathrm{Na} 2 \mathrm{HPO}_{4}, 1.8 \mathrm{mM} \mathrm{KH}_{2} \mathrm{PO}_{4}, \mathrm{pH} 7.4$ ), and incubated with FITC-conjugated Annexin $\mathrm{V}$ in binding buffer (0.01 M HEPES, $0.14 \mathrm{M} \mathrm{NaCl}, 2.5 \mathrm{mM} \mathrm{CaCl}_{2}$, pH 7.4) for $20 \mathrm{~min}$ at $37^{\circ} \mathrm{C}$ in the dark. After incubation, cells were washed and resuspended in $200 \mu \mathrm{l}$ PBS with $1 \%$ FCS, and then additionally incubated with $10 \mu \mathrm{l}$ of a PI solution $(1 \mathrm{mg} / \mathrm{ml})$. The Annexin V positive $(+) /$ PI negative $(-)$ cells, indicating early apoptotic cells, and the Annexin $\mathrm{V}$ positive $(+) / \mathrm{PI}$ positive $(+)$, indicating late apoptotic cells, were detected using a FACSCalibur (BD Biosciences, San Jose, USA). The results were analyzed using the CellQuest software (BD Biosciences, San Jose, USA). Annexin VFITC conjugates were detected with the FL1 channel of the FACSCalibur machine. Propidium iodide was read on the FL2 channel.

\subsection{Subcellular fractionation}

Cell nuclear extracts were obtained as previously described (Levrand et al., 2005). Briefly, cells were washed with PBS, collected, pelleted by centrifugation, and resuspended in lysis buffer [ $10 \mathrm{mM}$ HEPES, pH 7.9, $10 \mathrm{mM} \mathrm{KCl,} 0.1 \mathrm{mM}$ EDTA, supplemented with $1 \mathrm{mM}$ dithiothreitol (DTT), a complete mini protease inhibitor cocktail tablet and 0,4\% NP-40]. After 30 min on ice, the lysates were centrifuged at $16,000 \mathrm{~g}$ in a microcentrifuge for $5 \mathrm{~min}$ at $4{ }^{\circ} \mathrm{C}$. The supernatant was discarded and the pellet (nuclear fraction) was resuspended in nuclear extract buffer (20 mM HEPES, pH 7.9, $0.4 \mathrm{mM} \mathrm{NaCl} 1 \mathrm{mM}$ EDTA, supplemented with $1 \mathrm{mM}$ DTT, a complete mini protease inhibitor cocktail tablet and 10\% glycerol). After $1 \mathrm{~h}$ incubation at $4{ }^{\circ} \mathrm{C}$, the nuclear fraction was sonicated three times, for $1 \mathrm{~s}$ each, and centrifuged at $16,000 \mathrm{~g}$ for $5 \mathrm{~min}$ at $4{ }^{\circ} \mathrm{C}$. The supernatant was then collected and used as a nuclear extract.

Mitochondrial fraction was prepared as previously described (Kowluru and Abbas, 2003). Briefly, cells were washed with icecold PBS, and homogenized in the mitochondria buffer [250 mM sucrose, $20 \mathrm{mM}$ HEPES-KOH, pH 7.5, $10 \mathrm{mM} \mathrm{KCl}, 1.5 \mathrm{mM} \mathrm{MgCl}_{2}$, $0.5 \mathrm{mM}$ EDTA, supplemented with $1 \mathrm{mM}$ phenylmethylsulfonyl fluoride (PMSF) and a complete mini protease inhibitor cocktail tablet]. The homogenate was centrifuged at $750 \mathrm{~g}$ for $10 \mathrm{~min}$ at $4{ }^{\circ} \mathrm{C}$ to remove nuclei and unbroken cells, and the supernatant was centrifuged at $10,000 \mathrm{~g}$ for $15 \mathrm{~min}$. The resultant mitochondrial pellet was lysed in $50 \mu \mathrm{l}$ of the mitochondrial extract buffer (20 mM Tris, pH 7.4, $100 \mathrm{mM} \mathrm{NaCl}$, supplemented with $1 \mathrm{mM}$ PMSF and a complete mini protease inhibitor cocktail tablet).

\subsection{Western blot analysis}

For caspase-3 detection, cells were washed with cold PBS and lysed in the following buffer [ $150 \mathrm{mM} \mathrm{NaCl}, 50 \mathrm{mM}$ Tris, $5 \mathrm{mM}$
EGTA, pH 7.4, 1\% Triton X-100, 0.5\% DOC, 0.1\% sodium dodecyl sulphate (SDS), supplemented with complete mini protease inhibitor cocktail tablets and $1 \mathrm{mM}$ DTT]. Nuclear and mitochondrial cell fractions were used for AIF detection. Protein concentration was determined with the BCA protein assay kit. For caspase- 3 and AIF detection, $50 \mu \mathrm{g}$ and $20 \mu \mathrm{g}$ protein, respectively, from each sample, were used for Western blot analysis, after adding $6 \times$ concentrated sample buffer ( $0.5 \mathrm{M}$ Tris, $\mathrm{pH} 6.8,30 \%$ glycerol, $10 \%$ SDS, 0.6 M DTT, $0.012 \%$ bromophenol blue) and heating the samples for $5 \mathrm{~min}$ at $95^{\circ} \mathrm{C}$. Proteins were separated by sodium dodecyl sulphate-polyacrylamide gel electrophoresis (SDS-PAGE), using a $9 \%$ polyacrylamide gel. Then, the proteins were transferred electrophoretically to PVDF membranes. The membranes were blocked for $1 \mathrm{~h}$ at room temperature, in Tris-buffered saline (137 $\mathrm{NaCl} \mathrm{mM}$, 20 Tris- $\mathrm{HCl} \mathrm{mM}, \mathrm{pH}$ 7.6) containing $0.1 \%$ Tween-20 (TBS-T) and 5\% low-fat milk. Incubation with the primary antibodies, rabbit anticaspase-3 (1:500) and mouse anti-AIF (1:1000), was performed overnight at $4{ }^{\circ} \mathrm{C}$. After incubation, the membranes were washed four times, for $15 \mathrm{~min}$, in TBS-T with $0.5 \%$ low-fat milk, and incubated with an alkaline phosphatase-linked secondary goat antirabbit or goat anti-mouse (1:20,000 in TBS-T with $1 \%$ low-fat milk) for $1 \mathrm{~h}$ at room temperature. After washing the membranes $(4 \times 15 \mathrm{~min})$, protein immunoreactive bands were visualized, following incubation of the membrane with ECF reagent for $5 \mathrm{~min}$, on a Storm $860 \mathrm{Gel}$ and Blot Imaging System (Amersham, Uppsala, Sweden).

\subsection{Poly-caspase activation detection with fluorochrome-labeled inhibitors of caspases (FLICA)}

Carboxyfluorescein FLICA apoptosis detection kit (Immunochemistry Technologies, Bloomington, USA), that detects most of active caspases (caspase- $1,-3,-4,-6,-7,-8$ and -9 ), was used according with the manufacturer instructions. Briefly, after cell incubations, $30 \times$ FLICA solution was added, for $1 \mathrm{~h}$ at $37^{\circ} \mathrm{C}$, to the culture medium (1:30 ratio) of endothelial cells cultured on coverslips, protecting the cells from light. Cells were washed with $1 \times$ washing buffer (from the FLICA apoptosis detection kit), and then were stained with Hoechst 33342 and fixed for future viewing (up to $24 \mathrm{~h}$ later) under a fluorescence microscope (Leica, Wetzlar, Germany), using a bandpass filter (excitation $490 \mathrm{~nm}$, emission $>520 \mathrm{~nm}$ ) to detect the green fluorescence in cells with active caspases, and an UV-filter with excitation at $365 \mathrm{~nm}$ and emission at $480 \mathrm{~nm}$ for Hoechst detection.

\subsection{Immunocytochemistry}

Cells were fixed with a solution of $4 \%$ paraformaldehyde and $4 \%$ sucrose for $10 \mathrm{~min}$ at room temperature. Then, cells were rinsed twice in PBS and permeabilized with $1 \%$ Triton X-100 in PBS for 5 min. After blocking for 30 min with $10 \%$ goat serum in PBS with $0.2 \%$ Tween-20, cells were incubated with the primary antibody anti-AIF (1:100) for $90 \mathrm{~min}$. Cells were rinsed three times with PBS and incubated with Alexa 568-conjugated secondary antibody (goat anti-mouse IgG, 1:250). At the same time, the nuclei were stained with DAPI $(1: 2000)$. The preparations were visualized with an inverted fluorescence microscope (Leica, Wetzlar, Germany).

\subsection{Statistical analysis}

The data are expressed as mean \pm SEM. Statistical significance was determined by using a one-way analysis of variance (ANOVA), followed by Dunnet's or Bonferroni's post hoc tests, as indicated in the figure legends. 


\section{Results}

\subsection{High glucose, but not mannitol, decreases retinal endothelial cell viability}

It is well established that chronic hyperglycemia induces cell death in endothelial cells of retinal vessels. Here, rat retinal endothelial cells were exposed to $30 \mathrm{mM}$ glucose (high glucose) for 7 days (long-term exposure) to mimic chronic hyperglycemia. Since high glucose increases osmolarity, endothelial cells were also exposed to $24.5 \mathrm{mM}$ mannitol $(+5.5 \mathrm{mM}$ glucose in the culture medium), which is commonly used as an osmotic control. To analyze the effect of high glucose/osmolarity in cell viability we used the MTT assay. High glucose significantly decreased the MTT reduction to $79.1 \pm 2.1 \%$ of the control $(p<0.01$; Fig. $1 \mathrm{~A})$ whereas mannitol did not cause a significant decrease in the MTT reduction (93.8 $\pm 3.6 \%$ of the control).

\subsection{High glucose and mannitol decrease retinal endothelial cell proliferation}

Since endothelial cells were cultured for a long-term period (7 days), and high glucose and mannitol could affect cell proliferation, we evaluated whether the decrease in the MTT reduction caused by high glucose could also be due to a decrease in endothelial cell proliferation, using the [methyl- $\left.{ }^{3} \mathrm{H}\right]$-thymidine incorporation assay. High glucose and mannitol significantly decreased endothelial cell proliferation $(81.6 \pm 0.5 \%, p<0.01$, and $81.1 \pm 4.0 \%, \quad p<0.01$, respectively) compared with control (Fig. 1B).

\subsection{Nitric oxide donor (NOC-18) and $\mathrm{H}_{2} \mathrm{O}_{2}$ decrease retinal endothelial cell viability}

Since oxidative/nitrosative stress plays an important role in the pathogenesis of DR, and exposure to compounds that release free radicals is a commonly used strategy to mimic in vivo oxidative/ nitrosative stress conditions, endothelial cells were also exposed to NOC-18 $(250 \mu \mathrm{M})$ and $\mathrm{H}_{2} \mathrm{O}_{2}(100 \mu \mathrm{M})$, and cell viability was assessed $24 \mathrm{~h}$ later. NOC-18 and $\mathrm{H}_{2} \mathrm{O}_{2}$ caused a significant decrease in MTT reduction $(75.8 \pm 3.1 \%, p<0.01$, and $83.5 \pm 2.6 \%, p<0.01$, respectively) compared with control (Fig. 1C).

\subsection{High glucose, nitric oxide donor and $\mathrm{H}_{2} \mathrm{O}_{2}$ increase retinal endothelial cell apoptosis}

To confirm whether the decrease in the MTT reduction induced by high glucose and oxidative/nitrosative stress conditions was due to endothelial cell death, we quantified endothelial cell apoptosis by examining nuclear morphology of endothelial cells using Hoechst 33342. Cells with condensed and/or fragmented chromatin were considered apoptotic cells (Fig. 2). High glucose significantly increased the number of apoptotic cells $(8.8 \pm 0.4 \%$ of total cells, $p<0.01$ ) compared with the number of apoptotic cells in control cultures $(4.8 \pm 0.2 \%$ of total cells). The increase in osmolarity did not enhance apoptotic cell death, since the number of apoptotic cells in mannitol-treated cultures was similar to control. NOC-18 and $\mathrm{H}_{2} \mathrm{O}_{2}$ also caused a significant increase in the number of apoptotic cells $(13.7 \pm 0.5 \%, p<0.01$, and $14.0 \pm 1.5 \%, p<0.01$, of total cells, respectively) compared with control.

In cells undergoing apoptosis PS is exposed at the outer leaflet of plasma membrane. Annexin V binds specifically to PS allowing the discrimination between viable and apoptotic cells (Vermes et al., 2000). Endothelial cells were stained with Annexin V, and with PI, which allows detecting cells with disrupted membrane (Fig. 3). The Annexin V positive $(+) /$ PI negative $(-)$ cells (lower right panel), indicating early apoptotic cells, and the Annexin V (+)/PI $(+)$ cells (upper right panel), indicating late apoptotic cells, were detected by flow cytometry and quantified.

High glucose, but not mannitol, significantly increased the number of Annexin $\mathrm{V}(+)$ cells $(128.8 \pm 5.9 \%$ of the control, $p<0.01)$. NOC-18 and $\mathrm{H}_{2} \mathrm{O}_{2}$ also increased the number of Annexin $\mathrm{V}(+)$ cells $(148.0 \pm 10.4 \%, p<0.01$, and $153.4 \pm 9.0 \%, p<0.01$, of the control, respectively). NOC-18 and $\mathrm{H}_{2} \mathrm{O}_{2}$ also induced necrosis (upper left panel) in retinal endothelial cells. However, as can be seen in Fig. 3B, cell death occurred mainly by apoptosis.

\subsection{Caspase activation mediates $\mathrm{H}_{2} \mathrm{O}_{2}$-induced apoptosis, but not high glucose- and NOC-18-induced apoptosis, in retinal endothelial cells}

To check whether endothelial cell apoptosis induced by high glucose and oxidative/nitrosative stress conditions was mediated by caspase activation, the protein levels of active caspase- 3 , which results from proteolytic cleavage of pro-caspase-3, were measured by Western blotting. Active caspase- 3 was detected at low levels in control cells, and its levels significantly increased only in cells exposed to $\mathrm{H}_{2} \mathrm{O}_{2}(130.8 \pm 2.3 \%$ of the control, $p<0.01)$ (Fig. $\left.4 \mathrm{~A}\right)$. High glucose, mannitol and NOC-18 did not induce caspase- 3 activation. The protein levels of active caspase- 3 were also analyzed in endothelial cells exposed to high glucose or oxidative/nitrosative stress conditions for shorter periods, and we did not detect any differences compared with control (data not shown). Staurosporin (500 nM; $2 \mathrm{~h}$ ) was used as a positive control for active caspase-3 detection.
A

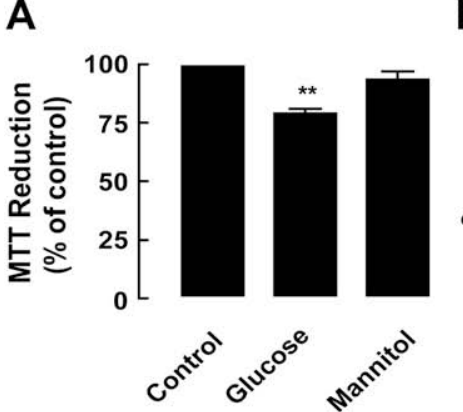

B

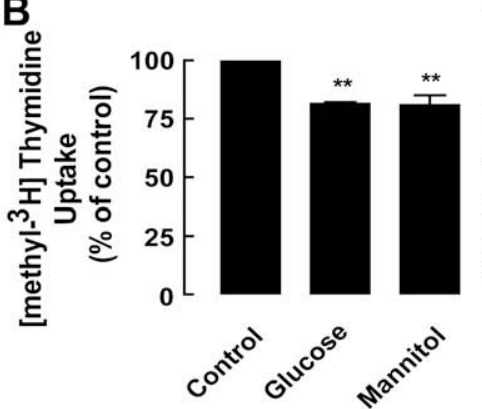

C

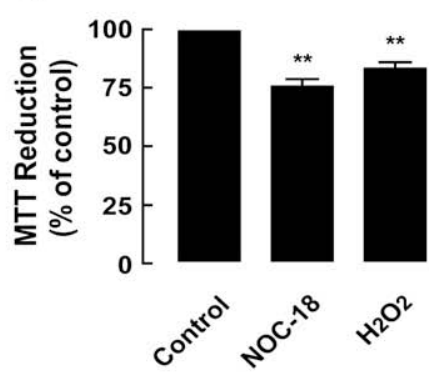

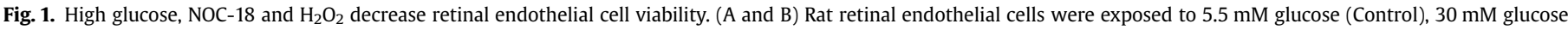

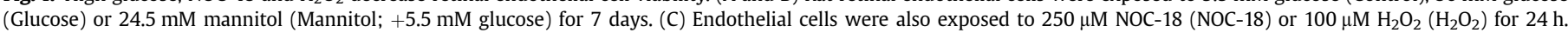

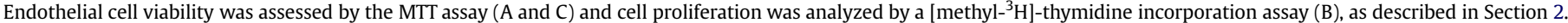

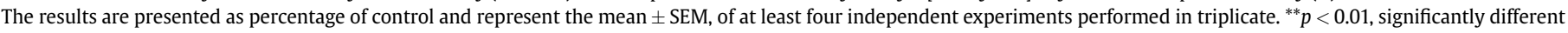
from control; Dunnet's post hoc test. 
A

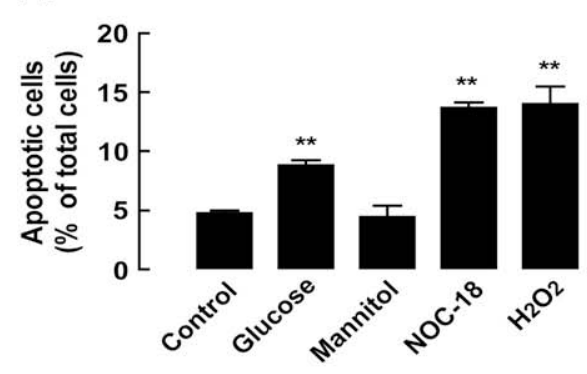

B Control

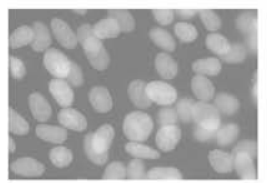

NOC-18
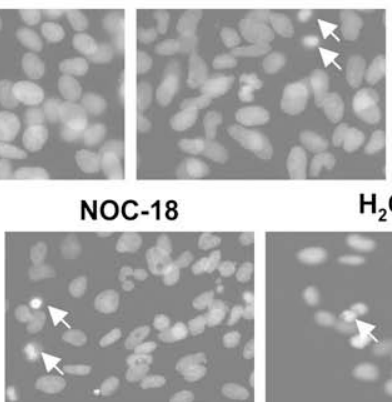

$\mathrm{H}_{2} \mathrm{O}_{2}$

Mannitol
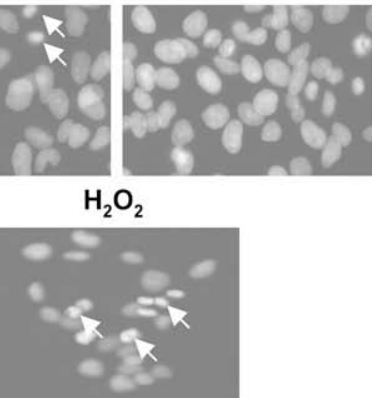

Fig. 2. High glucose, $\mathrm{NOC}-18$ and $\mathrm{H}_{2} \mathrm{O}_{2}$ increase the number of endothelial cells with condensed and/or fragmented chromatin. (A) Quantification of apoptotic cells in rat retinal endothelial cells exposed to $5.5 \mathrm{mM}$ glucose (Control), $30 \mathrm{mM}$ glucose (Glucose) or $24.5 \mathrm{mM}$ mannitol (Mannitol; $+5.5 \mathrm{mM}$ glucose) for 7 days. Also, endothelial cells were exposed to $250 \mu \mathrm{M}$ NOC-18 (NOC-18) or $100 \mu \mathrm{M} \mathrm{H}_{2} \mathrm{O}_{2}\left(\mathrm{H}_{2} \mathrm{O}_{2}\right)$ for $24 \mathrm{~h}$. The results are presented as percentage of total number of cells counted (non-apoptotic + apoptotic), and represent the mean \pm SEM, of at least five independent experiments. ${ }^{* *} p<0.01$, significantly different from control; Dunnet's post hoc test. (B) Representative images of control and treated endothelial cells with Hoechst staining. Arrows indicate cells with condensed and/or fragmented nuclei.

A
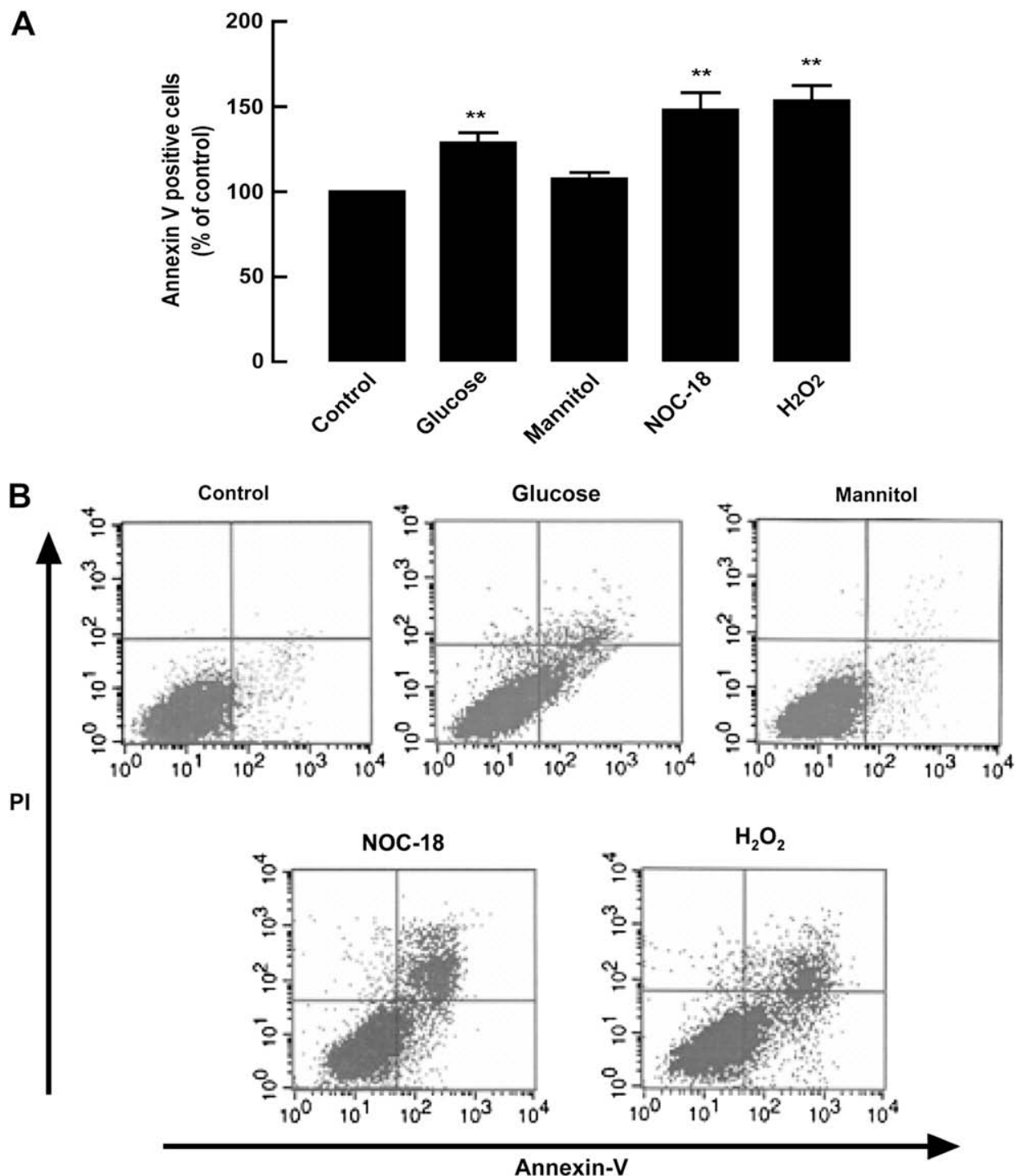

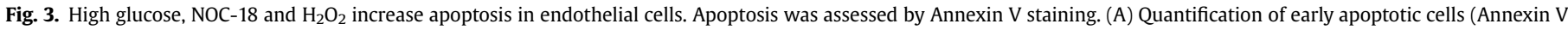

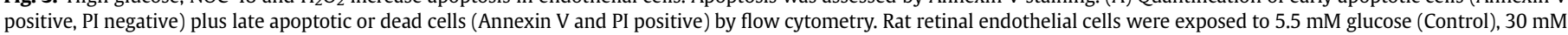

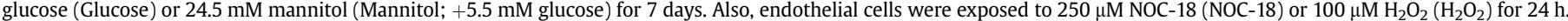

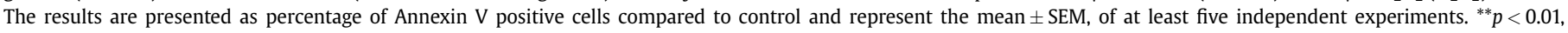
significantly different from control; Dunnet's post hoc test. (B) Representative dotplots of control and treated endothelial cells stained with Annexin V and PI. 


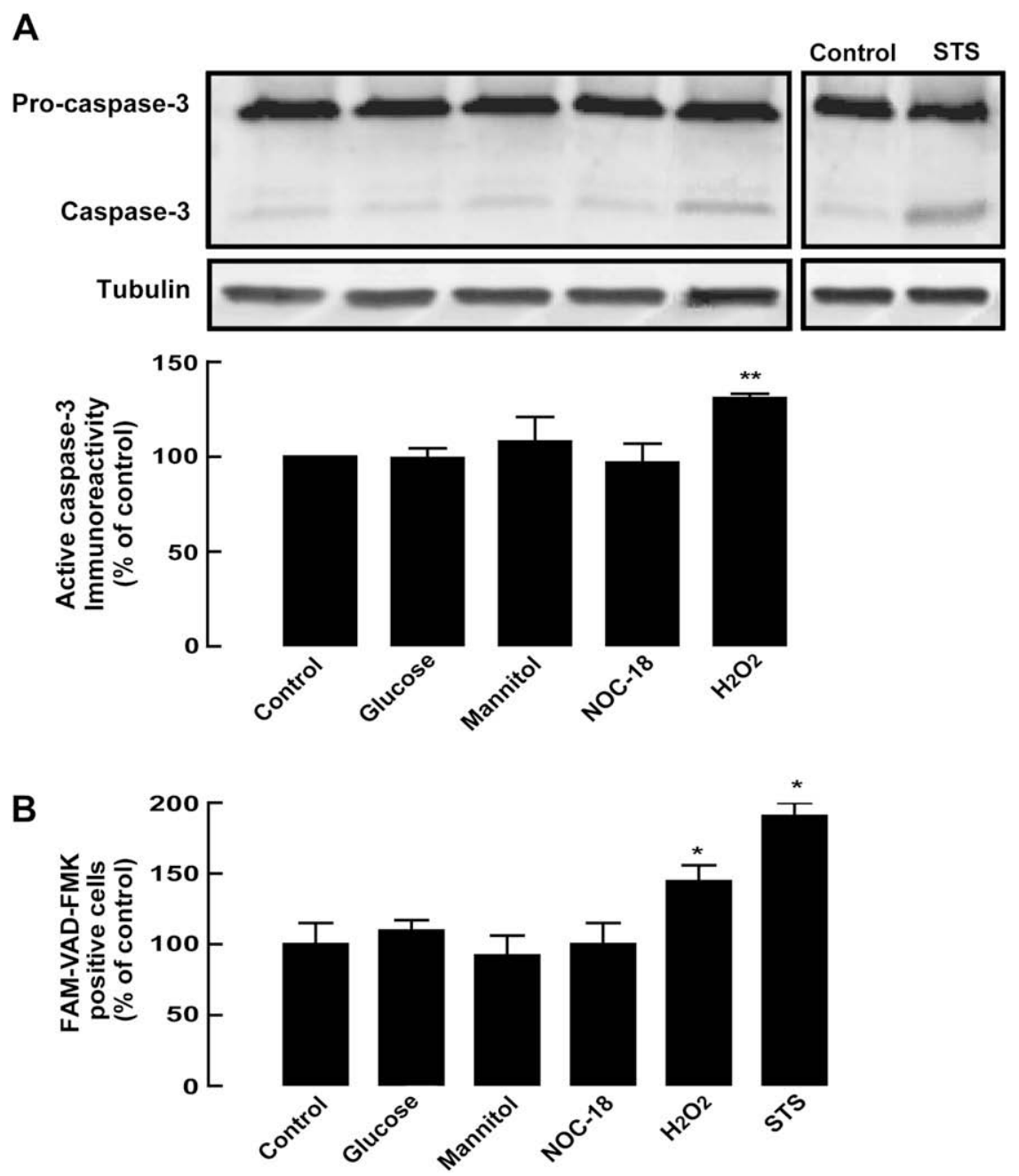

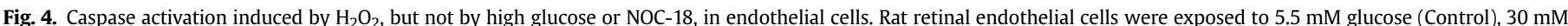

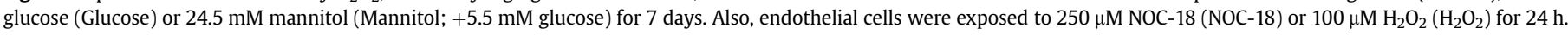

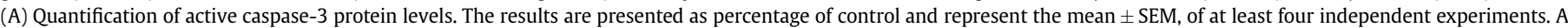

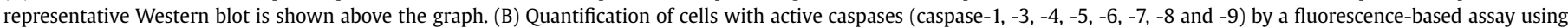

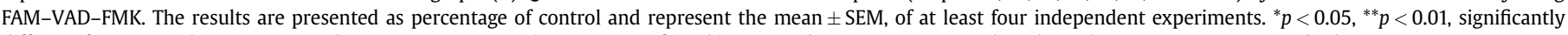
different from control; Dunnet's post hoc test. Staurosporin (STS; $500 \mathrm{nM}$, for $2 \mathrm{~h}$ ) was used as a positive control to show the caspase activation in both assays.

We also analyzed whether other caspases could be activated when endothelial cells were exposed to high glucose and oxidative/ nitrosative stress conditions, using a fluorescent inhibitor of caspase-1, $-3,-4,-5,-6,-7,-8$ and -9 , FAM-VAD-FMK that irreversibly binds to active caspases. Again, only $\mathrm{H}_{2} \mathrm{O}_{2}$ significantly increased the number of cells with active caspases to $144.5 \pm 11.3 \%$ of the control ( $p<0.05$; Fig. 4B). Again, staurosporin ( $500 \mathrm{nM} ; 2$ h) was used as a positive control for detection of active caspases.

3.6. AIF translocation to the nucleus correlates with high glucose-, NOC-18- and $\mathrm{H}_{2} \mathrm{O}_{2}$-induced apoptosis in retinal endothelial cells

Since high glucose and NOC-18, and $\mathrm{H}_{2} \mathrm{O}_{2}$, induced apoptosis in endothelial cells, and caspases were only activated in cells exposed to $\mathrm{H}_{2} \mathrm{O}_{2}$, apoptosis could be due to a caspase-independent mechanism. To analyze the potential involvement of AIF, the protein levels of AIF were quantified by Western blotting, in mitochondrial (Fig. 5A) and nuclear (Fig. 5B) cellular fractions. In endothelial cells incubated with high glucose there was a significant decrease $(74.6 \pm 4.2 \%$ of the control, $p<0.01)$ in mitochondrial AIF levels and a significant increase $(138.3 \pm 2.5 \%$ of the control, $p<0.05)$ in nuclear AIF levels. Mannitol did not alter AIF levels either in mitochondrial or nuclear fractions. In cells incubated with NOC-18 and $\mathrm{H}_{2} \mathrm{O}_{2}$, AIF levels decreased in mitochondrial extracts (71.7 $\pm 3.4 \%, p<0.01$, and $74.2 \pm 3.8 \%, p<0.01$, respectively) and increased in nuclear extracts $(148.2 \pm 7.1 \%, p<0.01$, and $165.5 \pm 12.3 \%, p<0.01$, respectively), compared to the control.

By immunocytochemistry, we also observed that AIF was mainly found in the perinuclear region in control conditions and in mannitol-treated cells. However, the immunoreactivity of AIF was clearly evident in the nuclei of cells exposed to high glucose and oxidative/nitrosative stress conditions (Fig. 6), corroborating the results obtained by Western blotting.

\section{Discussion}

The loss of endothelial cells in retinal capillaries occurs early in DR. Indeed, several reports have shown that retinal endothelial cells undergo apoptosis upon diabetes (Dagher et al., 2004; Du et al., 2003; Kern et al., 2000; Kowluru and Koppolu, 2002; Mohr et al., 2002). Apoptosis was also found in human, rat and bovine retinal endothelial cells exposed to high glucose (Behl et al., 2008; 
A
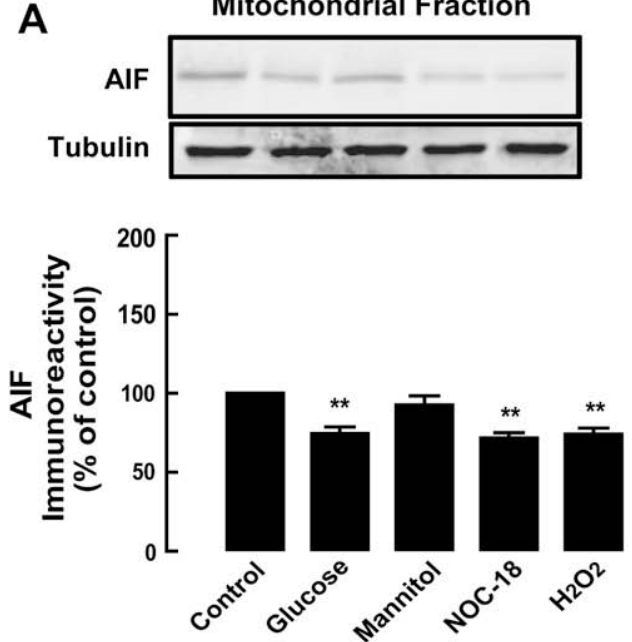

B
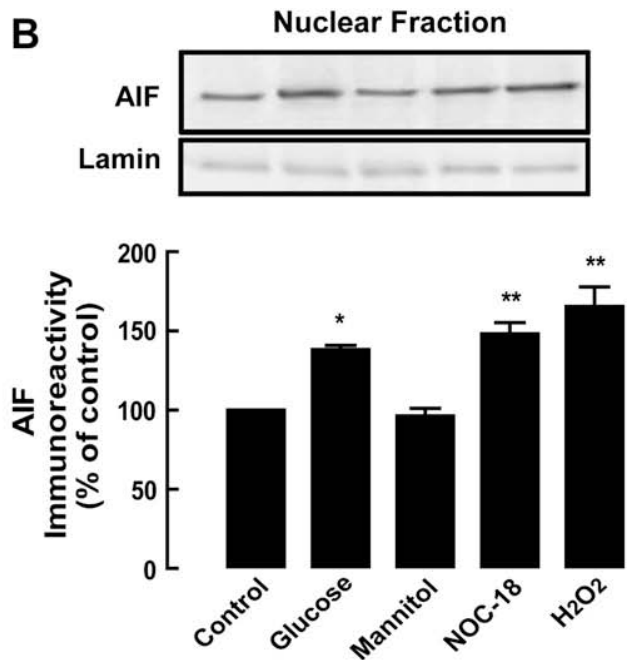

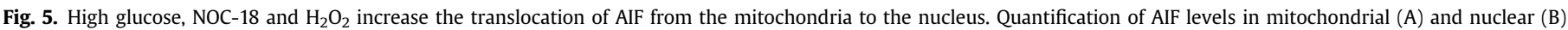

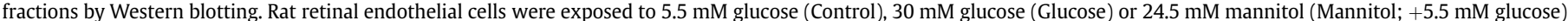

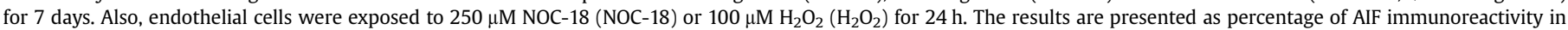

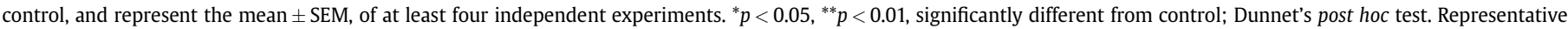
Western blots for AIF in mitochondrial (A) and nuclear (B) fractions are shown above graphs ( $\alpha$-tubulin and lamin B were used as loading controls, respectively).

Busik et al., 2008; Du et al., 2003; Kowluru and Abbas, 2003; Kowluru et al., 2006; Kowluru and Koppolu, 2002). Moreover, oxidative/nitrosative stress was shown to play a key role in endothelial cell death in DR. It has been demonstrated that antioxidants and the inhibition of nitric oxide production decrease diabetes- and high glucose-induced apoptosis in retinal endothelial cells (Du et al., 2002; Kowluru and Abbas, 2003; Kowluru and Koppolu, 2002; Sennlaub et al., 2002).

It has been shown that diabetes and high glucose induce apoptosis by a caspase-dependent pathway, involving several caspases, including caspase-3 (Behl et al., 2008; Busik et al., 2008; Kowluru and Abbas, 2003; Kowluru and Koppolu, 2002; Mohr et al., 2002). Nevertheless, it has been demonstrated in several disease models that apoptosis can be mediated by caspase-independent mechanisms, and apoptosis mediated by AIF can be also relevant (Leist and Jaattela, 2001). Some evidences support the involvement of caspase-independent apoptotic processes in retinal cells. In fact, we reported previously, and for the first time, that elevated glucose induces apoptosis in retinal neural cells by a caspase-independent mechanism. The increase in apoptosis was correlated with

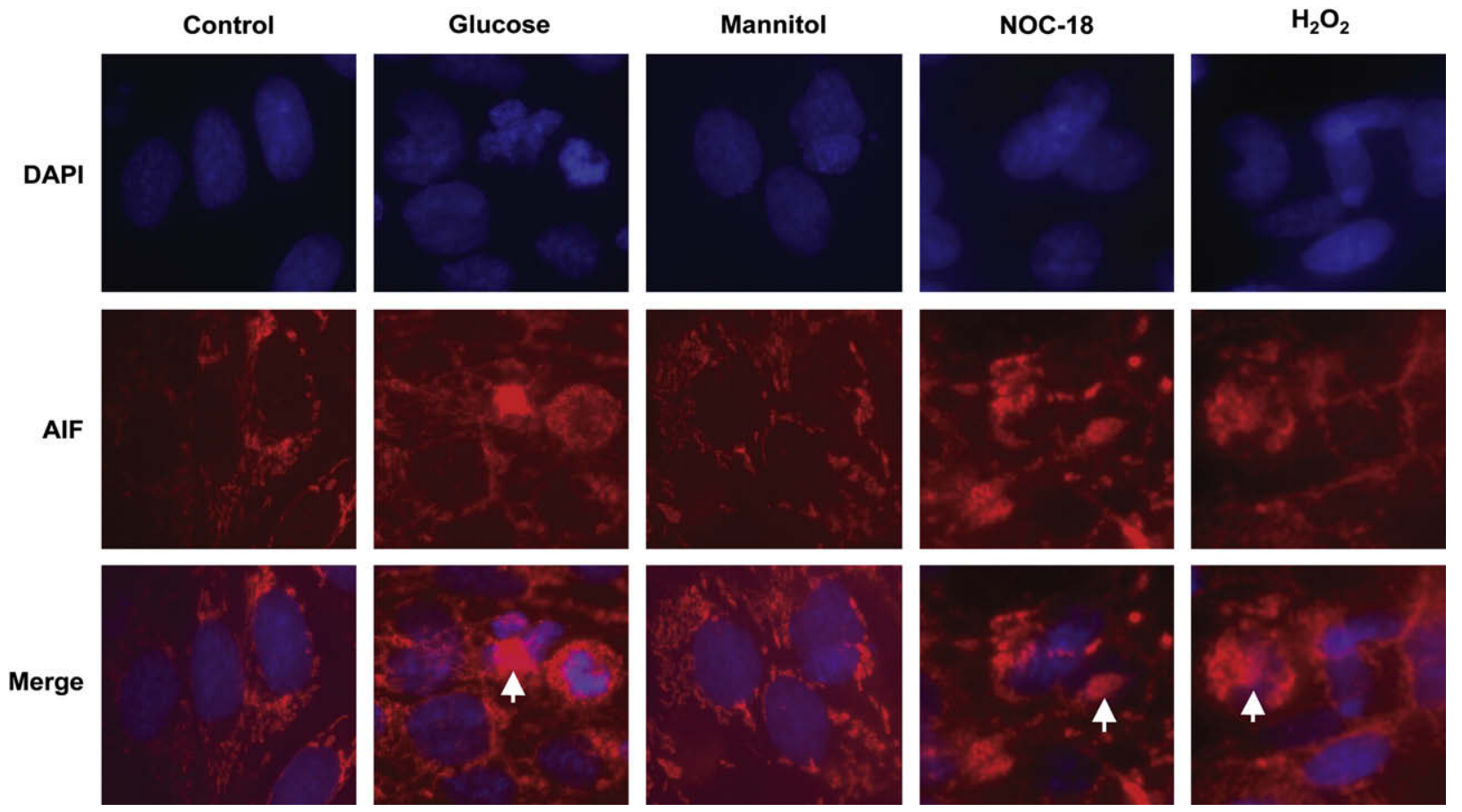

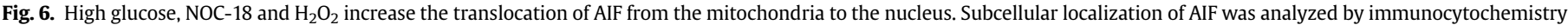

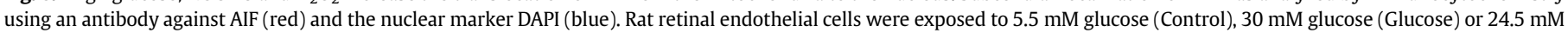
mannitol (Mannitol; $+5.5 \mathrm{mM}$ glucose) for 7 days. Also, endothelial cells were exposed to $250 \mu \mathrm{M} \mathrm{NOC}-18(\mathrm{NOC}-18)$ or $100 \mu \mathrm{M} \mathrm{H} \mathrm{H}_{2} \mathrm{O}_{2}\left(\mathrm{H}_{2} \mathrm{O}_{2}\right)$ for $24 \mathrm{~h}$. $400 \times$ magnification. 
a translocation of AIF from the mitochondria to the nucleus (Santiago et al., 2007). An upregulation of AIF levels in the retinas of diabetic patients was also recently reported. However, the translocation of AIF from the mitochondria to the nucleus was not demonstrated (Abu El-Asrar et al., 2007). In addition, rat ganglion cell death induced by TNF- $\alpha$ or hypoxia involves a caspase-independent component (Tezel and Yang, 2004). A caspase-independent cell death mediated by AIF translocation from mitochondria to the nucleus was found in dying photoreceptors in an experimental model of retinitis pigmentosa (Paquet-Durand et al., 2007; Sanges et al., 2006) and after retinal detachment (Hisatomi et al., 2001).

It was also reported that AIF can mediate apoptotic cell death in endothelial cells, namely in cerebral and coronary artery endothelial cells (Schoier et al., 2006; Zhang et al., 2004, 2005). Moreover, in human lung endothelial cells, it was found that oxidative stress induces apoptosis involving the translocation of AIF from the mitochondria to the nucleus (Liu et al., 2005). However, to date, and to our knowledge, there is no evidence demonstrating the involvement of AIF in retinal endothelial cell apoptosis.

In this work, we explored the potential involvement of caspasedependent and -independent apotosis in retinal endothelial cells exposed to high glucose and oxidative/nitrosative stress conditions. Surprisingly, we found neither an increase in the protein levels of active caspase- 3 nor an increase in the activation of other caspases in endothelial cells exposed to high glucose or to the nitric oxide donor, suggesting that in these conditions the increase in apoptosis was due to a caspase-independent mechanism, although in cells exposed to $\mathrm{H}_{2} \mathrm{O}_{2}$ there was an increase in active caspase- 3 levels and in the activity of caspases, suggesting that retinal endothelial cell apoptosis triggered by $\mathrm{H}_{2} \mathrm{O}_{2}$ is also mediated by caspases. Our results are not in accordance with previous reports showing that elevated glucose or diabetes induce caspase-dependent apoptosis in retinal endothelial cells (Busik et al., 2008; Kowluru and Abbas, 2003; Kowluru and Koppolu, 2002; Mohr et al., 2002). This discrepancy is likely due to the use of different in vitro models, bovine retinal endothelial cells (BRECs) or human retinal endothelial cells (HRECs). However, in HRECs, high glucose only induces a slight activation of caspases (Busik et al., 2008). In our model (TRiBRB2 cell line), caspases were activated when cells were exposed to $\mathrm{H}_{2} \mathrm{O}_{2}$ or staurosporin. Therefore, it appears that our cell culture model is more resistant to caspase activation, and the exposure to elevated glucose, or to NOC-18, was not sufficient to trigger an apoptotic cascade mediated by caspases.

Although the increase in osmolarity affected endothelial cell proliferation, the increase in apoptosis and AIF translocation from the mitochondria to the nucleus induced by elevated glucose was not due to an increase in osmolarity, since exposure to mannitol did not increase apoptosis and AIF translocation.

Our results demonstrate that hyperglycemic and oxidative/nitrosative stress conditions can activate a caspase-independent pathway in retinal endothelial cells, which suggests that endothelial cell apoptosis occurring in retinal vessels of diabetic humans and experimental models might also occur by caspase-independent mechanisms and is not mediated only by caspases. However, this hypothesis needs to be confirmed in experimental models of diabetes. It is not clear the reason why endothelial cells committed to die choose different apoptotic pathways, and also if different apoptotic pathways are activated in the same cell. Probably, the type and intensity of stress stimulae might trigger different apoptotic pathways.

In summary, these results give further insight into the molecular mechanisms underlying the pathogenesis of DR. We show for the first time that retinal endothelial cell apoptosis induced by elevated glucose, and by oxidative/nitrosative stress conditions, can be mediated by a caspase-independent pathway, and is correlated with the translocation of AIF from the mitochondria to the nucleus.

\section{Acknowledgments}

This work was supported by the Foundation for Science and Technology, Portugal (POCTI/CBO/38545/01; SFRH/BD/9686/2002), and FEDER.

\section{References}

Abu El-Asrar, A.M., Dralands, L., Missotten, L., Geboes, K., 2007. Expression of antiapoptotic and proapoptotic molecules in diabetic retinas. Eye 21, 238-245.

Allen, D.A., Yaqoob, M.M., Harwood, S.M., 2005. Mechanisms of high glucoseinduced apoptosis and its relationship to diabetic complications. J. Nutr. Biochem. 16, 705-713.

Behl, Y., Krothapalli, P., Desta, T., DiPiazza, A., Roy, S., Graves, D.T., 2008. Diabetesenhanced tumor necrosis factor-alpha production promotes apoptosis and the loss of retinal microvascular cells in type 1 and type 2 models of diabetic retinopathy. Am. J. Pathol. 172, 1411-1418.

Busik, J.V., Mohr, S., Grant, M.B., 2008. Hyperglycemia-induced reactive oxygen species toxicity to endothelial cells is dependent on paracrine mediators. Diabetes 57, 1952-1965.

Cunha-Vaz, J.G., 1983. Studies on the pathophysiology of diabetic retinopathy. The blood-retinal barrier in diabetes. Diabetes 32 (Suppl. 2), 20-27.

Dagher, Z., Park, Y.S., Asnaghi, V., Hoehn, T., Gerhardinger, C., Lorenzi, M., 2004. Studies of rat and human retinas predict a role for the polyol pathway in human diabetic retinopathy. Diabetes 53, 2404-2411.

Du, Y., Miller, C.M., Kern, T.S., 2003. Hyperglycemia increases mitochondria superoxide in retina and retinal cells. Free Radic. Biol. Med. 35, 1491-1499.

Du, Y., Smith, M.A., Miller, C.M., Kern, T.S., 2002. Diabetes-induced nitrative stress in the retina, and correction by aminoguanidine. J. Neurochem. 80, 771-779.

Hammes, H.P., 2005. Pericytes and the pathogenesis of diabetic retinopathy. Horm. Metab. Res. 37 (Suppl. 1), 39-43.

Hisatomi, T., Sakamoto, T., Murata, T., Yamanaka, I., Oshima, Y., Hata, Y., Ishibashi, T., Inomata, H., Susin, S.A., Kroemer, G., 2001. Relocalization of apoptosis-inducing factor in photoreceptor apoptosis induced by retinal detachment in vivo. Am. J. Pathol. 158, 1271-1278.

Hosoya, K., Tomi, M., Ohtsuki, S., Takanaga, H., Ueda, M., Yanai, N., Obinata, M. Terasaki, T., 2001. Conditionally immortalized retinal capillary endothelial cell lines (TR-iBRB) expressing differentiated endothelial cell functions derived from a transgenic rat. Exp. Eye Res. 72, 163-172.

Joza, N., Susin, S.A., Daugas, E., Stanford, W.L., Cho, S.K., Li, C.Y., Sasaki, T., Elia, A.J. Cheng, H.Y., Ravagnan, L., Ferri, K.F., Zamzami, N., Wakeham, A., Hakem, R. Yoshida, H., Kong, Y.Y., Mak, T.W., Zuniga-Pflucker, J.C., Kroemer, G. Penninger, J.M., 2001. Essential role of the mitochondrial apoptosis-inducing factor in programmed cell death. Nature 410, 549-554.

Kern, T.S., Tang, J., Mizutani, M., Kowluru, R.A., Nagaraj, R.H., Romeo, G., Podesta, F. Lorenzi, M., 2000. Response of capillary cell death to aminoguanidine predicts the development of retinopathy: comparison of diabetes and galactosemia. Invest. Ophthalmol. Vis. Sci. 41, 3972-3978.

Kowluru, R.A., 2005. Diabetic retinopathy: mitochondrial dysfunction and retinal capillary cell death. Antioxid. Redox. Signal. 7, 1581-1587.

Kowluru, R.A., Abbas, S.N., 2003. Diabetes-induced mitochondrial dysfunction in the retina. Invest. Ophthalmol. Vis. Sci. 44, 5327-5334.

Kowluru, R.A., Atasi, L., Ho, Y.S., 2006. Role of mitochondrial superoxide dismutase in the development of diabetic retinopathy. Invest. Ophthalmol. Vis. Sci. 47, 1594-1599.

Kowluru, R.A., Koppolu, P., 2002. Diabetes-induced activation of caspase-3 in retina: effect of antioxidant therapy. Free Radic. Res. 36, 993-999.

Leist, M., Jaattela, M., 2001. Four deaths and a funeral: from caspases to alternative mechanisms. Nat. Rev. Mol. Cell Biol. 2, 589-598.

Levrand, S., Pesse, B., Feihl, F., Waeber, B., Pacher, P., Rolli, J., Schaller, M.D. Liaudet, L., 2005. Peroxynitrite is a potent inhibitor of NF-\{kappa\}B activation triggered by inflammatory stimuli in cardiac and endothelial cell lines. J. Biol. Chem. 280, 34878-34887.

Li, P., Nijhawan, D., Budihardjo, I., Srinivasula, S.M., Ahmad, M., Alnemri, E.S. Wang, X., 1997. Cytochrome c and dATP-dependent formation of Apaf-1/caspase-9 complex initiates an apoptotic protease cascade. Cell 91, 479-489.

Liu, P.L., Chen, Y.L., Chen, Y.H., Lin, S.J., Kou, Y.R., 2005. Wood smoke extract induces oxidative stress-mediated caspase-independent apoptosis in human lung endothelial cells: role of AIF and EndoG. Am. J. Physiol. Lung Cell Mol. Physiol. 289, L739-749.

Lorenzi, M., Gerhardinger, C., 2001. Early cellular and molecular changes induced by diabetes in the retina. Diabetologia 44, 791-804.

Mohr, S., Xi, X., Tang, J., Kern, T.S., 2002. Caspase activation in retinas of diabetic and galactosemic mice and diabetic patients. Diabetes 51, 1172-1179.

Mosmann, T., 1983. Rapid colorimetric assay for cellular growth and survival: application to proliferation and cytotoxicity assays. J. Immunol. Methods 65 55-63.

Otera, H., Ohsakaya, S., Nagaura, Z., Ishihara, N., Mihara, K., 2005. Export of mitochondrial AIF in response to proapoptotic stimuli depends on processing at the intermembrane space. EMBO J. 24, 1375-1386.

Paquet-Durand, F., Silva, J., Talukdar, T., Johnson, L.E., Azadi, S., van Veen, T., Ueffing, M., Hauck, S.M., Ekstrom, P.A., 2007. Excessive activation of 
poly(ADP-ribose) polymerase contributes to inherited photoreceptor degeneration in the retinal degeneration 1 mouse. J. Neurosci. 27, 10311-10319.

Sanges, D., Comitato, A., Tammaro, R., Marigo, V., 2006. Apoptosis in retinal degeneration involves cross-talk between apoptosis-inducing factor (AIF) and caspase-12 and is blocked by calpain inhibitors. Proc. Natl. Acad. Sci. U S A 103 , 17366-17371.

Santiago, A.R., Cristovao, A.J., Santos, P.F., Carvalho, C.M., Ambrosio, A.F., 2007. High glucose induces caspase-independent cell death in retinal neural cells. Neurobiol. Dis. 25, 464-472.

Schoier, J., Hogdahl, M., Soderlund, G., Kihlstrom, E., 2006. Chlamydia (Chlamydophila) pneumoniae-induced cell death in human coronary artery endothelia cells is caspase-independent and accompanied by subcellular translocations of Bax and apoptosis-inducing factor. FEMS Immunol. Med. Microbiol. 47, 207-216.

Sennlaub, F., Courtois, Y., Goureau, O., 2002. Inducible nitric oxide synthase mediates retinal apoptosis in ischemic proliferative retinopathy. J. Neurosci. 22, 3987-3993.

Srinivasula, S.M., Ahmad, M., Fernandes-Alnemri, T., Litwack, G., Alnemri, E.S., 1996 Molecular ordering of the Fas-apoptotic pathway: the Fas/APO-1 protease Mch is a $\mathrm{CrmA}$-inhibitable protease that activates multiple Ced-3/ICE-like cysteine proteases. Proc. Natl. Acad. Sci. U S A 93, 14486-14491.

Susin, S.A., Lorenzo, H.K., Zamzami, N., Marzo, I., Snow, B.E., Brothers, G.M., Mangion, J., Jacotot, E., Costantini, P., Loeffler, M., Larochette, N., Goodlett, D.R Aebersold, R., Siderovski, D.P., Penninger, J.M., Kroemer, G., 1999. Molecular characterization of mitochondrial apoptosis-inducing factor. Nature 397, 441-446.

Tezel, G., Yang, X., 2004. Caspase-independent component of retinal ganglion cell death, in vitro. Invest. Ophthalmol. Vis. Sci. 45, 4049-4059.

The Diabetes Control and Complications Trial Research Group, 1993. The effect of intensive treatment of diabetes on the development and progression of longterm complications in insulin-dependent diabetes mellitus. N. Engl. J. Med. 329, 977-986.

UK Prospective Diabetes Study (UKPDS) Group, 1998. Intensive blood-glucose control with sulphonylureas or insulin compared with conventional treatment and risk of complications in patients with type 2 diabetes (UKPDS 33). Lancet 352, 837-853.

Vermes, I., Haanen, C., Reutelingsperger, C., 2000. Flow cytometry of apoptotic cell death. J. Immunol. Methods 243, 167-190.

Zhang, W., Li, D., Mehta, J.L., 2004. Role of AIF in human coronary artery endothelial cell apoptosis. Am. J. Physiol. Heart Circ. Physiol. 286, H354-358.

Zhang, W., Shokeen, M., Li, D., Mehta, J.L., 2003. Identification of apoptosis-inducing factor in human coronary artery endothelial cells. Biochem. Biophys. Res. Commun. 301, 147-151.

Zhang, Y., Zhang, X., Park, T.S., Gidday, J.M., 2005. Cerebral endothelial cell apoptosis after ischemia-reperfusion: role of PARP activation and AIF translocation. J. Cereb. Blood Flow Metab. 25, 868-877.

Zou, H., Li, Y., Liu, X., Wang, X., 1999. An APAF-1.cytochrome c multimeric complex is a functional apoptosome that activates procaspase-9. J. Biol. Chem. 274, 11549-11556. 